\author{
УДК 65.01;331.101;658.336 \\ JEL J24; M21 \\ DOI https://doi.org/10.17721/tppe.2021.43.2
}

\author{
Alina Magomedova, \\ $\mathrm{PhD}$ in Economics, Associate Professor \\ Department of Business Economics, Faculty of Economics \\ Taras Shevchenko National University of Kyiv
}

\title{
WORKFORCE POTENTIAL AS AN ESSENTIAL COMPONENT IN THE DEVELOPMENT OF BUSINESS MODELS
}

Business models have undergone significant transformations in recent years. All changes, both positive and negative, were largely caused by the COVID-19 pandemic and its effects. Companies have been forced to digitalise their business models while employees had to work on improving their digital skills.

This paper identifies and explores the up-to-date features of a company's business model. They are related to the innovative nature of design and development of business models; flexibility and adaptability to the dynamic conditions of the market environment; change management, the development of robust resource capacity; compliance with environmental trends and the principles of responsible consumption, and, undeniably, growing online presence.

A company's business model, and in particular the level of its flexibility and adaptability to the external environment, is a core economic category that needs improvement and additional investment. Business models are complex systems. Understanding the role of each individual element in the system and the set of these elements overall is an extremely important task. Workforce is one of the essential components and a strategic resource for companies in the development of their business models. However, workforce as a key resource has the greatest value only once its potential is discovered and fully utilised. Therefore, one of the major objectives for companies today is to develop their workforce potential.

This paper presents a study of workforce potential, i.e. its professional component, as an essential element for the development of a company's business model. The findings propose a set of skills, namely soft skills, which recent graduates - one of the most active groups in the job market - might lack or need in order to meet their own professional ambitions and the needs of employers today. In addition, it is concluded that the problem of worrkforce potential development requires a comprehensive approach. The paper suggests a vision of the role and participation of each stakeholder in solving the task of developing workforce potential.

Keywords: business model, workforce potential, soft skills, personnel, digitalisation.

Problem statement. Over the last few years, representatives of business communities worldwide and in Ukraine have had to overcome a number of challenges in order to retain their market positions. New business environments have triggered the development of new areas aimed at ensuring company growth. Digital skills, adaptability, creative approach to the development of value proposition, continuous improvement and transformation of business models - this is a non-exhaustive list of trends that have emerged in the business environment today and that modern companies have to meet.

The availability and utilisation of cutting-edge technologies and resources help modern-day companies achieve their goals and remain competitive in the market. In our opinion, time and staff represent strategic resources of any modern company. By time, we understand a 
company's ability to adapt quickly to change and ability to find optimal approaches to solving problems. Whereas staff is seen not as just a group of employees, but a well-coordinated team that makes joint efforts towards achieving one common outcome. These resources are interconnected and interdependent. However, it is worth emphasising that it is staff that represents the driving force behind success, and the development of workforce potential is a strategic task for any company and the development of its business model.

Literature review. In their studies, N. Revutskaya, G. Shvydanenko, and A. Slyvotsky explored theoretical issues of business modelling; I. Adizes, R. Kaplan, D. Norton, A. Osterwalder, and S. Pimenov studied different tools for developing and improving business models, whereas O. Gassman, K. Frankenberger, G. Chesbro, and M. Csik studied and generalised information on trend-setting templates for business models.

Unresolved part of the problem. Existing research is mostly aimed at the study of business processes and their role in business modelling. However, in our opinion, today the emphasis on the effectiveness of business models has somewhat shifted. Despite increasing role of automation and robotisation, company staff - a powerful team of employees remains to be a critical resource for any company. Nevertheless, its role and qualitative characteristics have changed in recent years under the influence of the coronavirus crisis. Therefore, the development of workforce potential is both a challenge for a modern company and one of the main factors in shaping the success of its business model.

The purpose of this paper is to identify the prerequisites for effective performance of business models and to determine the need to develop workforce potential as an essential condition for the development of a company's business model.

Research methodology. The theoretical background and methodology of the paper is based on a set of general and specific methods, principles, rules and techniques of scientific research, justified by given topic and purpose. Methods of induction and deduction were used to determine the modern prerequisites for the development of effective business models and to define workforce potential as one of the prerequisites for the development of a company's business model; analysis and synthesis, comparison and graphics methods were used to visualize the attitude of different generations to their employers, as well as to demonstrate the findings of the author's research on skills development among graduates of higher education institutions; logical, systemic and structural analysis methods were used to summarise the recommendations on the approach to solving the problem of development of workforce potential.

Findings of the study. Present-day business models have a number of distinctive features, which on the one hand provide companies with a higher level of competitive advantage, and on the other, increase the level of uncertainty and doubt in the implementation of business activities. Today, business model is defined not only as an approach to creating and implementing a value proposition for the client, which in turns generates profits for the company. Business model is a much broader concept, a complex system of relationships in the corporate ecosystem. Accordingly, each participant in this system must understand its role and contribution, which ultimately affects the place and status of the company in this general ecosystem. Today, a successful way to improve or even transform a business model involves understanding and identifying the company's role and needs of all stakeholders 
(partners, competitors, suppliers, employees, etc.), together with solid awareness of modern technologies and the latest market trends [3].

Companies have two main ways to adapt their business model to changes and new challenges. The first is related to the use of existing business model templates that have already been implemented by other companies. The second method involves expanding the horizons of current business environment in search for innovative solutions and, consequently, developing innovative models that go beyond the normal and obvious perception of the industry, products, and customers.

A successful business model is not just a pool of revolutionary solutions, the formation of a radically new view of traditional methods of activity, product production and customer satisfaction. The success of a business model is linked with a company's capacity for internal organisation and coherence [3].

We see how trends in business models have changed over the past few years. The vast majority of them now have digital elements and can be implemented remotely, even in industries that have traditionally been based on offline components and implementation modes, such as medicine, sports, entertainment, etc. The characteristics of business models today are related to the company's ability to shape and adjust innovations. Classical business models, which have remained relevant and effective for many years, no longer work today. Only those who have been able to quickly adapt to the changes dictated by the reality of the COVID-19 pandemic have remained in the market, as well as those who have managed not only to adapt, but also to start forming new reality and shaping trends on their own.

Today, among other prerequisites for the company's development is its ability to change the business model significantly faster than previously expected by the market [3]. The competitive edge of any company has become extremely short-term today. Systematic analysis and review of competitive advantages, and, based on the results - developing proposals for improvement is the only way to stay in trend.

Implementation of business models from other areas than the company's field of activity today is another precondition and a key component in the development of a successful company.

Responsible consumption and environmental friendliness - these trends have persisted over the last years. Value propositions of many products increasingly meet these requirements, which, in turn, correlate with the global problems of humankind - reducing the negative impact of waste on the environment and preserving the natural ecosystem.

Customer orientation is ensured by high level of automation while maintaining and even increasing the level of personalisation. Customer identification is one of the essential conditions for the development and adaptation of a business model to the new needs.

Managing and updating resources holds a central place in the development of a business model. Therefore, personnel is seen as a company's core resource, whereas development and realisation of workforce is a strategically important task for any company.

Development of workforce potential is a systematic process of creating the most favourable conditions and opportunities for employees to realise their professional competence based on acquired knowledge, skills, abilities and experience, together with nurturing both personal and professional potential of employees in order to achieve utmost effectiveness. 
Today, we already witness a situation where representatives of Generation Z are becoming increasingly active participants in the labour market. Their main competences include strong digital skills; their motivation to work is related to job satisfaction, having an interesting team, opportunities to learn and develop, minimizing formal and bureaucratic elements in communication between peers, a sense of the importance of their contribution to the company, etc.

Fig. 1 presents the findings of a survey of the most active categories in the labour market today, i.e. millennial (persons born in 1980 - 2000-2004) and post-millennial or generation Z (born after 2004), on their views and loyalty to employers [1].

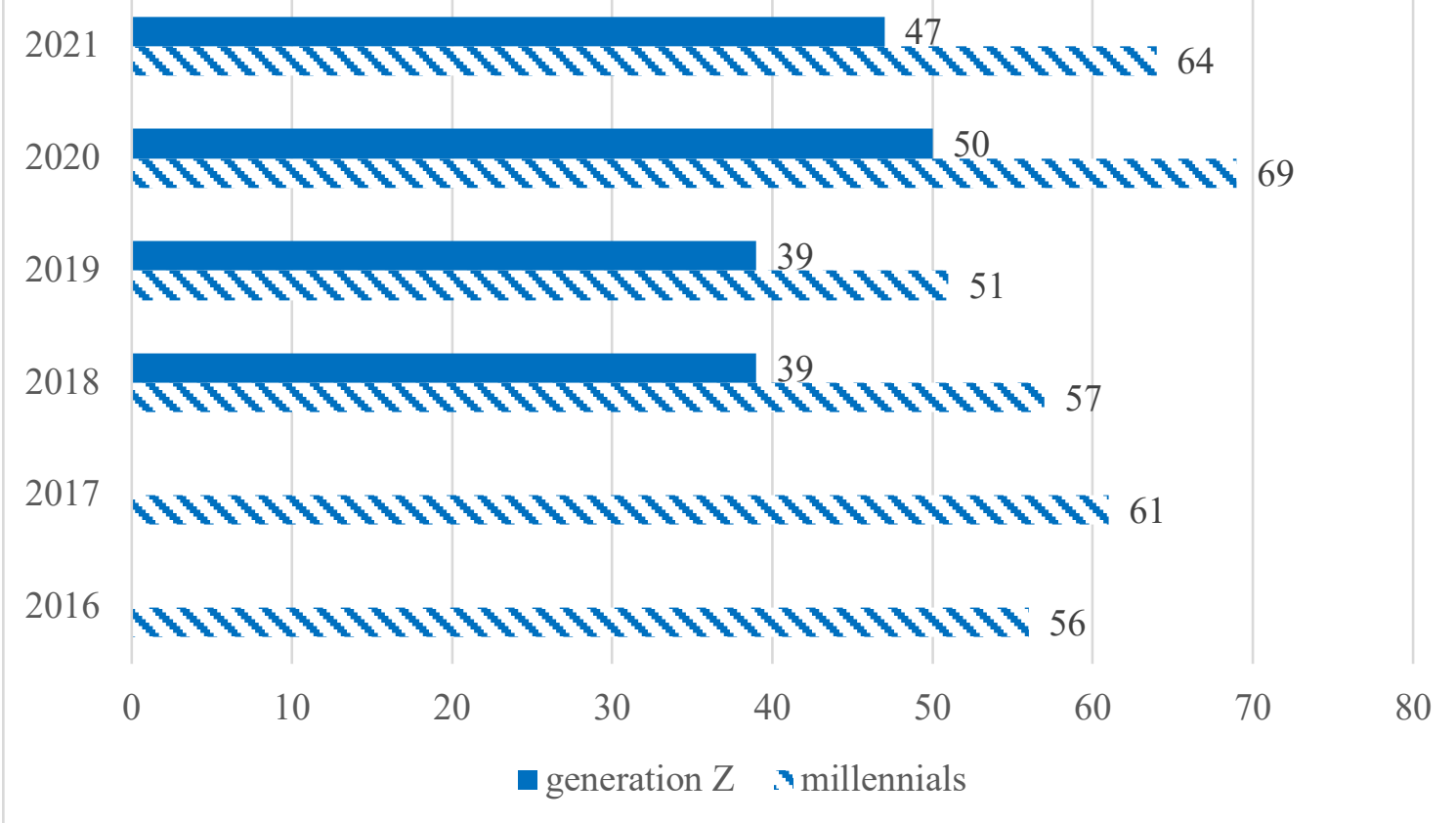

Fig. 1. Level of loyalty to employers among millennial and generation Z, \%, 2020-2021 Source: based on [4] results.

Studies have shown that the younger generation has much higher expectations and requirements for the employer. It is worth highlighting that in this case the level of loyalty is represented by respondents who plan to stay in Ukraine and realise their employment potential in the country.

It is important that the issue of workforce potential is strategic for the state. In this context, it deals with retaining workforce potential due to high level of emigration from the country. The problem of formation and development of workforce potential of the company is a micro-level problem, however, in our opinion, the solution should take place synchronously at several levels: at level of state, level of company, and level of consciousness of each individual employee.

The development of workforce potential takes place on the basis of the educational component, which is closely intertwined with the economic one. Level of remuneration directly depends on the qualification, experience and skills of an employee.

We conducted a study where respondents were graduates of one of the most promising and highly paid specialisms in economics. The aim of the study was to find out the views of 
graduates on acquisition of skills necessary for career development, and specifically the socalled soft skills, and their priorities in improving those. This study is motivated by the opinion of employers, who claim that students in the $4^{\text {th }}$ to $6^{\text {th }}$ years of study acquire a powerful set of hard skills. They are able to demonstrate in practice their knowledge and skills formed in the university classroom. However, soft skills are competencies that, in the job market today, are an integral part and requirement of a modern professional that are also contributing most to their career growth. Moreover, it is the approach to the development of soft skills that, according to employers, needs to be improved, since graduates mostly lack those or demonstrate at very basic level. Of course, some soft skills of recent graduates are formed exclusively in the workplace in the process of systematic and continuous execution of handson professional tasks. However, there is also a set of skills that are being developed during study.

Fig. 2 demonstrates the findings on the priorities of soft skills development among graduates in 2020 and 2021.

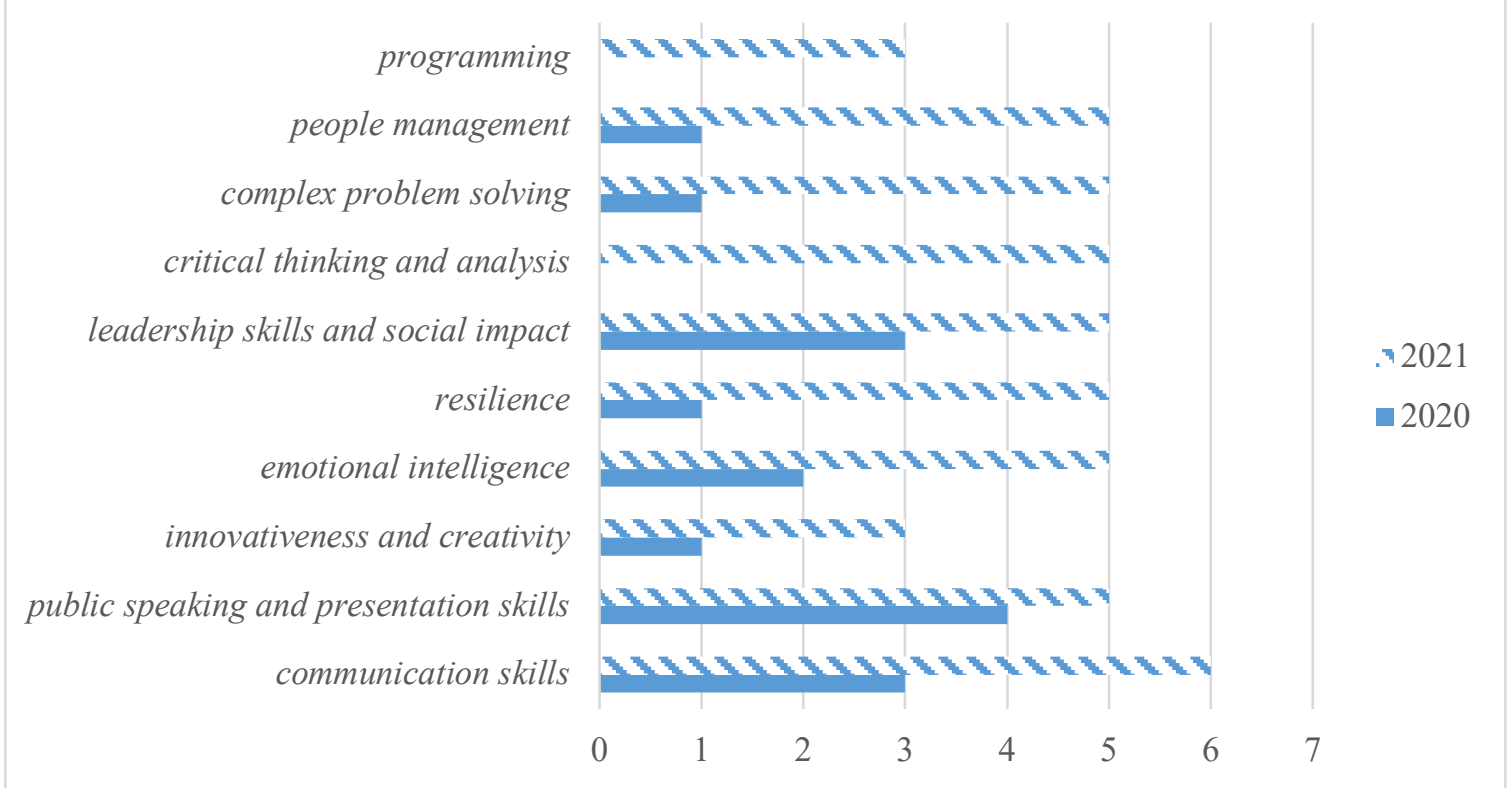

Fig. 2. Development of soft skills among graduates: priority areas, $\%, 2020-2021$ Source: based on the results of own research

The findings of the survey demonstrate that in 2020, most respondents sought to master public speaking skills and presentation skills. In 2021, the priority is given to the development of communication skills. This leads to a conclusion that these are direct consequences of the global COVID-19 pandemic, and the respondents made this choice based on the outcomes of remote learning. In fact, upon returning to the classroom (and to workplaces, as most graduates are normally employed at the time of graduation), students experienced some difficulties in building relationships with peers. In general, the results of the student survey in 2021 showed a greater lack of soft skills, which can be explained by self-isolation, remote learning and working from home.

Determining the priority of soft skills development, in 2020, respondents identified the top three most important skills to develop as follows:

- resilience (100\%);

- critical thinking and analysis; communication; complex problem solving (83.3\%); 
- emotional intelligence (66.7\%).

In 2021, the priority in the development of soft skills was seen as follows:

- communication (100\%);

- resilience and complex problem solving (83,3\%);

- critical thinking and analysis; emotional intelligence and leadership skills (over $50 \%$ ).

Hence, such results can be explained by the unforeseen outburst of the COVID-19 pandemic in 2020, which came as a shock and affected respondents' professional and everyday life. The level of uncertainty in 2020 invoked a high level of stress on the population of Ukraine and the whole world in general. Respondents, despite their young age and relatively high demand in the labour market, still felt the impact of severe fluctuations that affected their views on professional development. Having adapted to dramatic changes in life, in 2021 respondents pay greater importance to the development of communication skills. This trend is evidenced by limited opportunities for the development of communication skills and their realisation in both personal and professional life.

In addition, when answering questions about the impact of specific groups of people on their professional development, graduates determined that, first of all, in 2020 these groups consisted of friends, classmates, and employers; whereas in 2021 - classmates and employers. It should be noted that the impact of teachers on the formation of professional development of students in 2020 was mentioned by only $20 \%$ of respondents, whereas in 2021 this number increased to $50 \%$. This trend is a consequence of introduction of the remote learning - when neither teachers nor students were ready for this new mode of instruction. Adaptation took some time, but has also reduced the gap between students and teachers, as solving problematic issues and selecting comfortable modes of learning, online tools, and software had to be carried out in close cooperation and required reaching mutual understanding [5].

Thus, the study of the level and priority of soft skills development among graduates of one of the most popular specialisms in the job market helped determine the need and importance of employees' professional development. It helps companies explore and effectively realise professional potential of their teams, which increases the chances of companies to build and develop a successful business model. Moreover, the findings of the study prove the existence of certain problems in the field of education resulting from forced introduction of remote learning. However, these shortcomings can be quickly offset by the involvement of the employer, whose task is to ensure the development of the company's workforce potential and professional development of each individual employee. It is obvious that the development of the company's workforce potential is impossible without additional investment. Fig. 3 presents average investment in workforce in Ukraine. 


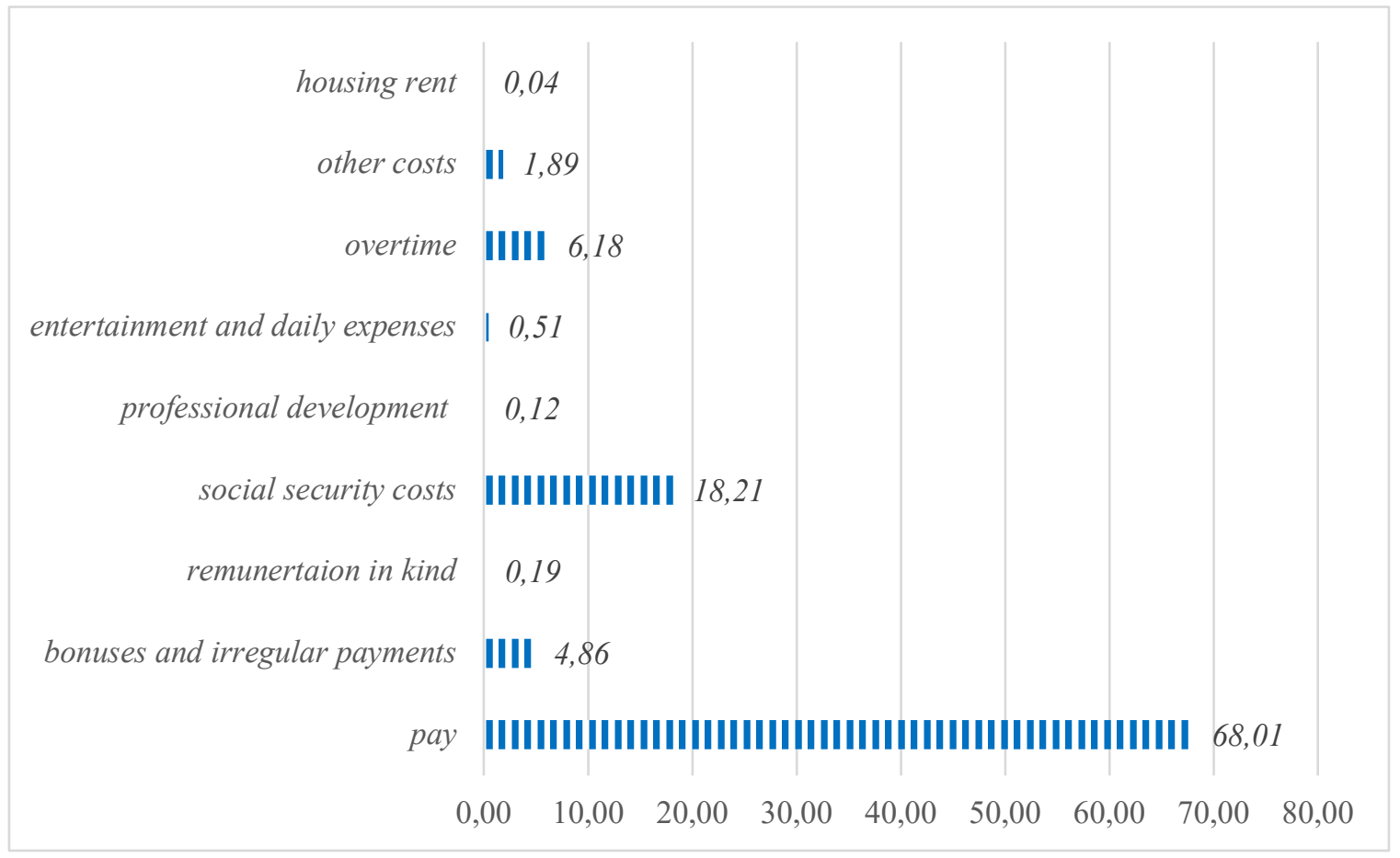

Fig. 3. Average monthly labour costs per full-time employee, \%, 2018

Source: based on data [2].

It can be seen that investment in professional development is well below $1 \%$ of the overall labour costs. In addition, even though it is understandable that the company's overall financial provision determines the level of investment in staff, we see that even with limited financing of economic activity, the costs of entertainment and daily expenses are higher than the costs of professional development. Clearly, this is a matter of priorities. Moreover, unfortunately, the latest official statistics dates back to 2018, which indicates a low interest on the part of public authorities in studying this issue.

Conclusions. Over the last few years, we have seen significant transformational changes that affected dramatically both the business environment and each and every citizen of the world. The COVID-19 pandemic has significantly affected all spheres of socioeconomic life. Positively, the pandemic stimulated the development of many economic and educational processes. The educational environment today is developing in a qualitatively new digital dimension. However, the quality of education provided in this new way may still be under doubt. This is evidenced by findings of a survey of graduate students regarding the level of soft skills. Studies have shown that graduates already experience certain problems and difficulties with communication, which are a consequence of self-isolation and lack of regular personal contact. Lack of relevant soft skills inevitably affects professional development of graduates. The problem of developing competences is also noted by employers themselves - they cannot fully utilise company's workforce potential to improve the performance and overall effectiveness.

However, in our opinion, solving this problem is not a task exclusively for the employees themselves (in our study - graduates of higher educational institutions). We see solutions to the problem in close cooperation between all the major stakeholders: employees, employers, government agencies, and higher educational institutions. Accordingly, the process of selfdevelopment and lifelong learning are tasks that are set to all the participants of the labour 
market today. It is worth emphasising that companies are employing more and more Generation Z employees, who demonstrate inflated expectations and requirements for employers, including those related to the need to develop the company's workforce potential and investment in employees' professional development. In view of this, investing in professional development, training, and overall investment in the development of company's workforce potential are strategic tasks for the employer.

Development of incentive measures for companies to stimulate investment in their employees, as well as ensuring collection of relevant information regarding the level of such investment are key action points for government authorities.

For educational institutions, the main task should be to review the curricula and include disciplines, specific topics and tasks designed to facilitate the development of students' soft skills.

Only this comprehensive approach shall contribute to the development of workforce potential, lead to improved performance of business models and help solve a number of socio-economic problems in Ukraine.

Prospects for further research are related to in-depth study of other areas and approaches to developing workforce potential in order to build effective and successful business models.

\section{References}

1. Strauss William, Hove Neil (1991) Generations : the history of America's future. 1584 to 2069. New York : Perennial, -544 p.

2. Витрати на робочу силу за 2018 р. Державна служба статистики України. URL: http://www.ukrstat.gov.ua/druk/publicat/kat_u/2019/zb/10/zb_vrs2018.pdf (дата звернення: 01.11.21)

3. Гассман О., Франкенбергер К., Шик М. Характеристики Бизнес-модели. 55 лучших шаблонов / пер. с англ. Бакушева К., М, 2017. 432 с.

4. A call for accountability and action. The Deloitte global 2021 millennial and gen z survey. URL: file:///Users/ali/Downloads/2021-deloitte-global-millennial-survey-report.pdf (дата звернення: 01.11.21)

5. Магомедова A.M. Сучасні навички випускників: погляд через призму наслідків COVID19. Сучасні виклики та пріоритетні напрями збереження та розвитку трудового потенціалу України: матеріали Всеукраїнської міждисциплінарної науково-практичної конференції (м. Київ, 21 жовтня 2021 р.), 2021. C.75-77.

6. Цифрова освіта. URL: https://osvita.diia.gov.ua/ (дата звернення: 01.11.21)

7. Цифрова трансформація освіти і науки. URL: https://mon.gov.ua/ua/tag/cifrovatransformaciya-osviti-ta-nauki (дата звернення: 01.11.21)

*Scientific research was conducted within the state budget theme No19BF042-01M Social and legal principles for preservation and development of workforce potential in Ukraine. 
Магомедова А.М., доцент

КНУ імені Тараса Шевченка

\section{ТРУДОВИЙ ПОТЕНЦІАЛ ЯК ПЕРЕДУМОВА РОЗВИТКУ БІЗНЕС-МОДЕЛІ КОМПАНІЇ}

Сучасні бізнес-моделі компаній зазнали істотних трансформацій за останні роки. Всі зміни, як позитивні, так і негативні, більшою мірою були спричинені пандемією COVID-19 та іï наслідками. Компаніям довелось забезпечити цифровізацію моделей бізнесу, а працівникам попрацювати над підвищенням рівня цифррових навичок. Разом з тим, незважаючи на динамічну діджиталізацію більшості процесів на підприємствах, персонал залишається ключовим ресурсом, а розвиток трудового потенціалу компанії - основною передумовою розвитку бізнес-моделі компанії та досягнення нею конкурентних переваг. Персонал, як ключовий ресурс, має високу цінність, коли його потенціал розкрито та використано повною мірою. Відповідно, сьогодні перед компаніями постає задача розвитку трудового потенціалу. У иій роботі представлено дослідження трудового потенціалу (професійної складової) як передумови розвитку бізнесмоделі компанії та представлено бачення ролі та участі кожного стейкхолдера у вирішенні проблеми розвитку трудового потенціалу компанії.

Ключові слова: бізнес-модель, трудовий потенціал компанії, soft skills, персонал, діджиталізація. 